\title{
TREATMENT OF POOL WATER INSTALLATION WASHINGS IN A FLOCCULATION/ULTRAFILTRATION INTEGRATED SYSTEM
}

\author{
Edyta Łaskawiec ${ }^{1}$, Mariusz Dudziak' ${ }^{1}$ Joanna Wyczarska-Kokot ${ }^{1}$ \\ 1 Institute of Water and Wastewater Engineering, Silesian University of Technology, Konarskiego 18, \\ 44-100 Gliwice, Poland \\ * Corresponding author's e-mail: edyta.laskawiec@polsl.pl
}

Received: 2017.04.22

Accepted: 2017.08.01 Published: 2017.09.01

\begin{abstract}
The article presents the possibilities of employing an integrated flocculation/ultrafiltration system in the treatment of washings generated upon the rinsing of filter beds in pool water installations. Single ultrafiltration process was used as a comparator. Flocculation was carried out using commercial dialuminium pentahydroxychloride solution widely used at pool facilities for the removal of contaminants in flocculation processes. The studies consisted in determination of correlations between the conditions of the flocculation process (variable doses of $\mathrm{Al}^{3+}$ ions: from 4 to $280 \mathrm{mg} / \mathrm{L}$ ) and the transport/separation characteristics of ultrafiltration membranes. Flocculation was performed at different temperatures of washings i.e. 8,21 , and $30^{\circ} \mathrm{C}$ for each of the pre-defined doses. Ultrafiltration was highly capable of reducing the turbidity of washings and removing a large group of contaminants as determined by turbidimetry and $\mathrm{UV}_{254}$ absorbance measurements. The studies revealed that the best transport/ separation characteristics of ultrafiltration membranes were obtained in a system in which ultrafiltration was performed following flocculation of washings carried out at $21{ }^{\circ} \mathrm{C}$ using a $40 \mathrm{mgAl}^{3+} / \mathrm{L}$ solution. The turbidity was reduced by ca. $99 \%$ and UV absorption was reduced by ca. $94 \%$ while the relative volumetric stream of the permeate increased by more than $35 \%$ (as compared to the filtration of washings in a singleprocess system). Membrane ultrafiltration significantly increased the quality of the waste stream consisting of washings from the pool water installation. Pre-processing of washings is required before ultrafiltration in order to limit the blocking of membrane pores. Flocculation may be one of such pre-processing methods.
\end{abstract}

Keywords: pressure driven membrane processes; washings, flocculation, waste streams treatment, ultrafiltration

\section{INTRODUCTION}

Filtration is the main element of the pool water treatment process. Most commonly, pool facilities make use of single-layer or multi-layer pressure filters in which surface coagulation is employed for the removal of contaminants. Rinsing of pressure filter beds is required in order to remove the contaminants accumulated during the filtration process, to prevent clogging and wear of the filtration material and to condition the beds for continued efficient operation. Rinsing is usually accomplished using water collected from a compensation tank (installed within the pool water treatment circuit). Water consumption should be in the range of $4-6 \mathrm{~m}^{3} / \mathrm{m}^{2}$ of bed surface area. Rinsing is accomplished at elevated flow speeds $(60-65 \mathrm{~m} / \mathrm{h})$ with air and/or water moving against the direction of filtration and thus setting the filter bed particles in motion. In order to protect the beds from excess growth of biological membranes and potentially pathogenic microbes being flushed into the pool water circulation, filter bed rinsing is required every 48 hours [GIS 2014, DIN 1997, Wyczarska-Kokot and Błotnicki 2013]. The process requires large volumes of water (monthly 
consumption for a single $1800 \mathrm{~mm}$ filter is 125 to $185 \mathrm{~m}^{3}$ ) which is usually discharged directly into sewage as wastewater. State-of-the-art water purification and wastewater treatment technologies are aimed at limiting the quantities of contaminants entering the aqueous environment as well as at reducing the consumption of water by means of effective recovery. Pressure-driven membrane processes that facilitate generation of water streams characterized by high purification rates depending on the technology (transmembrane pressure) and polymer (membrane type) used become increasingly popular. The techniques are not associated with any need to use additional chemical agents that might contain additives and microcontaminants hazardous for human health and the environment. Washings discharges as wastewater streams from pool installations are characterized by high turbidity, high total suspended solids, free chlorine and total phosphorus levels, as well as high COD (chemical oxygen demand) and $\mathrm{BOD}_{5}$ (5-day biological oxygen demand) values [Wyczarska-Kokot 2016]. High turbidity has a marked impact on the ultrafiltration process, particularly with regard to its transport characteristics, as it may clog membrane pores thus hampering the flow and shortening the membrane life cycle [Łaskawiec et al. 2016].

The goal of the study was to implement an integrated flocculation and membrane ultrafiltration system and to determine the impact of the operational parameters of flocculation (flocculant dose and process temperature) on the improvement of the transport and separation properties of membranes. Transport properties were assessed on the basis of the changes in the volumetric stream of the permeate. Separation of contaminants was assessed by means of turbidity and $\mathrm{UV}_{254}$ absorbance retention rates.

\section{MATERIALS AND METHODS}

\section{Characteristics of the washings}

The washings used in the study consisted of the stream of wastewater from the rinsing of multilayer pressure filters installed in an indoor sporting pool water purification system. The pool is characterized by high use rates (15-35 users/ hour). The main physicochemical parameters of the washings are presented in Table 1.

\section{Analytical procedures}

The quality of the washings was assessed before and after the treatment on the basis of selected physicochemical parameters. The measurements of the conductivity and $\mathrm{pH}$ of samples were carried out using a multiparametric inoLab $^{\circledR} 740$ meter (WTW). Ultraviolet absorbance at $254 \mathrm{~nm}$ was measured using an UV VIS Cecil 1000 spectrometer from Analytik Jena AG using a sample cell with optical path $\mathrm{d}$ of $1 \mathrm{~cm}$. $\mathrm{UV}_{254}$ absorbance values were measured according to a method disclosed by US EPA [Potter and Wimsatt 2009] and final results were expressed in $\mathrm{m}^{-1}$. $\mathrm{UV}_{254}$ measurement is a substitute for total organic carbon (TOC) analysis, providing information on the potential for the formation of byproducts during disinfection. However, one must keep in mind that the measurement is not fully selective [Nowacka and Włodarczyk-Makuła 2012, Mołczan et al. 2006]. The turbidity of samples was assessed by means of a TN-100 turbidimeter from EUTECH Instruments. Color was measured using an UV VIS Spectroquant ${ }^{\circledR}$ Pharo 300 spectrometer (Merck) at $340 \mathrm{~nm}$ wavelength.

\section{Operating parameters of the flocculation process}

Flocculation of washings was accomplished using a commercial Flockfix product from Chemoform AG, consisting of dialuminium pentahydroxychloride solution and widely used at pool facilities. The colorless liquid was characterized by the density of $1.024 \mathrm{~g} / \mathrm{cm}^{3}$ and the active substance concentration within the range of $2.5 \%$ to $10 \%$ as declared by the manufacturer. Flocculation was carried out on the basis of classical laboratory jar tests: 1 minute of rapid stirring (250 $\mathrm{rpm}$ ) followed by 25 minutes of flocculation with stirring speed of $20 \mathrm{rpm}$. The entire process was carried out in a four-jar tester (Velp Scientifica). Flocculation was performed at varying temperatures of washings i.e. 8,21 , and $30^{\circ} \mathrm{C}$ for each of

Table 1. Physicochemical parameters of the washings

\begin{tabular}{|l|c|c|}
\hline \multicolumn{1}{|c|}{ Parameter/Indicator } & Unit & Value \\
\hline $\mathrm{pH}$ & - & 7.14 \\
\hline Conductivity & $\mu \mathrm{S} / \mathrm{cm}$ & 960.00 \\
\hline Turbidity & $\mathrm{NTU}$ & 26.60 \\
\hline Color $\left(\mathrm{C}_{\mathrm{pt}}\right)$ & $\mathrm{mgPt} / \mathrm{L}$ & 306.00 \\
\hline Absorbance $\left(\mathrm{UV}_{254}\right)$ & $\mathrm{m}^{-1}$ & 23.50 \\
\hline
\end{tabular}


the pre-defined doses, i.e. for $4,8,40$, and 280 $\mathrm{mgAl}{ }^{3+} / \mathrm{L}$. The temperature conditions were adopted to follow the storage variants being in use for the washings. These included: Variant 1: outdoor reaction (flocculation) tank in spring/summer season or a sedimentation tank located in in pool basement $\left(21^{\circ} \mathrm{C}\right)$. Variant 2: outdoor reaction (flocculation) tank in winter season $\left(8^{\circ} \mathrm{C}\right)$. Variant 3: flow-through tank in the course of the filtration process being carried out directly after filter rinsing $\left(30^{\circ} \mathrm{C}\right)$. After completion of the flocculation process, the washings were left in the tanks for about 24 hours before the membrane filtration of the supernatant liquid. Ultrafiltration yielded a waste stream consisting of concentrated retentate including the contaminants being filtered off at the membrane.

\section{Methodology of membrane filtration}

Membrane filtration was carried out using an MW ultrafiltration membrane from GE Osmonics Inc. (USA). The characteristics of the membrane as well as the operational parameters of the filtration process are presented in Table 2.

The membrane was placed in a $380 \mathrm{~cm}^{3}$ steel filtration cell equipped with a magnetic stirred. Before the filtration, the membrane was conditioned by filtering deionized water until stable volumetric stream of the permeate was obtained. The filtration was carried out in a unidirectional (dead end) filtration system until $50 \%$ of the feed was recovered. In this time, selected physicochemical parameters were monitored in sequential $25 \mathrm{~mL}$ permeate samples and the volumetric stream of the permeate was determined. Six measurements were carried out for each run. After each cycle including filtration following flocculation in predefined conditions, the membrane was rinsed with deionized water to remove residual suspended solids deposited on the membrane's surface. The volumetric stream of deionized water permeate was determined again to facilitate determination of the membrane pore clogging rate.

The transport characteristics of membranes used in the filtration processes were assessed on the basis of volumetric stream of deionized water $\mathrm{J}_{\mathrm{w}}$ (measured upon the membrane being conditioned with water) and $\mathrm{J}_{\mathrm{w}}$ (measured upon proper filtration) using the following equation:

$$
J_{w}=\frac{v}{F \cdot t} ; \frac{m^{3}}{m^{2} s}
$$

where $\mathrm{v}$ is the volume of water of permeate in $\mathrm{m}^{3}$;

$\mathrm{F}$ is the active surface area in $\mathrm{m}^{2}$, and $\mathrm{t}$ is the time of filtration in $\mathrm{s}$.

Retention (R) was determined as part of the assessment of the separation characteristics of membranes, its value being calculated from the reductions in individual contamination rates:

$$
R=\left(1-\frac{C_{p}}{C_{n}}\right) \cdot 100 ; \%
$$

where $c_{p}$ is the concentration of contaminants within the permeate (index value) and $\mathrm{C}_{\mathrm{n}}$ is the concentration of contaminants in the feed (index value).

The intensity of the reduction of the transport properties of the membrane (the degree of pore

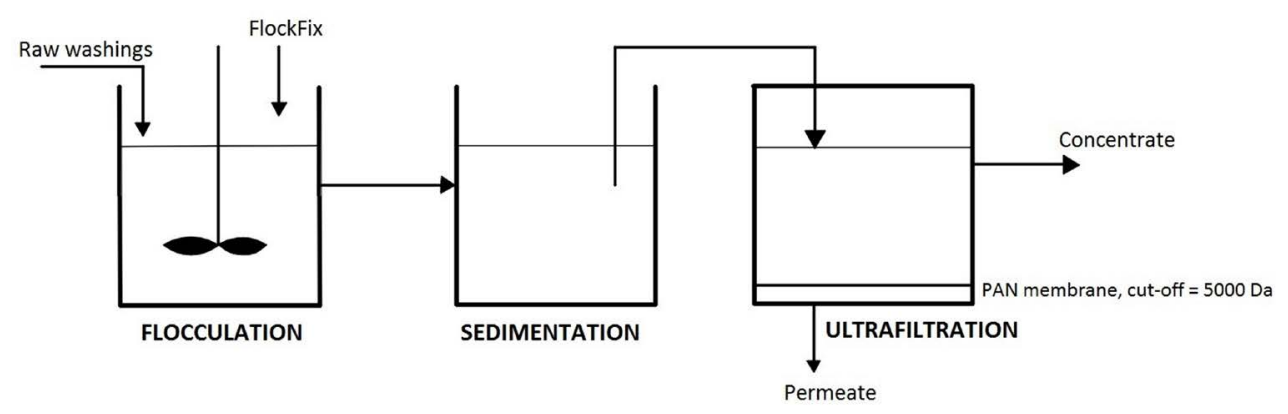

Figure 1. An outline of the integrated system used in the study

Table 2. Characteristics of ultrafiltration membrane and operational parameters of processes

\begin{tabular}{|c|c|c|c|c|}
\hline Membrane material & $\begin{array}{c}\text { Molecular weight } \\
\text { cut-off, } \mathrm{Da}\end{array}$ & $\begin{array}{c}\text { Active membrane } \\
\text { filtration area } \mathrm{F}, \mathrm{m}^{2}\end{array}$ & $\begin{array}{c}\text { Transmembrane } \\
\text { pressure } \Delta \mathrm{P}, \mathrm{MPa}\end{array}$ & $\begin{array}{c}\text { Volumetric stream of } \\
\text { deionized water permeate } \\
\mathrm{Jw} \cdot 10^{-5}, \mathrm{~m}^{3} / \mathrm{m}^{2} \mathrm{~s}\end{array}$ \\
\hline Polyacrylonitrile (PAN) & 50000 & 0.00385 & 0.2 & 3.78 \\
\hline
\end{tabular}


blocking) was determined from the relative volumetric stream of the permeate:

$$
\alpha=\frac{J_{w}}{J_{v}}
$$

where $\mathrm{J}_{\mathrm{w}}$ is the volumetric stream of the permeate at the sixth point of measurement in $\mathrm{m}^{3} / \mathrm{m}^{2} \cdot \mathrm{s}$, and

$\mathrm{J}_{\mathrm{v}}$ is the volumetric stream of deionized water in $\mathrm{m}^{3} / \mathrm{m}^{2} \cdot \mathrm{s}$.

\section{RESULTS}

The presence of contaminants and post-coagulation slurries with various particle sizes contributed to a marked reduction in the transport characteristics of the ultrafiltration membrane. The value of the relative volumetric stream of the permeate $\alpha$ upon the filtration of raw washings was 0.53 . Implementation of flocculation before membrane ultrafiltration improved the membrane transport characteristics in most attempts (Figure 2 ). The highest increases in the transport properties were obtained in the filtration of washings previously subjected to flocculation in solutions containing 40 and $280 \mathrm{mgAl}^{3+} / \mathrm{L}$ (at $21^{\circ} \mathrm{C}$ ). The relative streams of permeates were 0.82 and 0.73 , respectively for these doses.

In integrated systems including flocculation being carried out at $30^{\circ} \mathrm{C}$, reduction in the relative volumetric stream of the permeate was observed for increasing $\mathrm{Al}^{3+}$ doses. No such correlation could be observed at the other two predefined process temperatures.

Presented below are detailed results of the studies of the effect of preliminary flocculation of contaminants present within the washings on the separation properties of ultrafiltration membranes. Figures $3 \mathrm{a}$ and $3 \mathrm{~b}$ presents the contaminant reten-

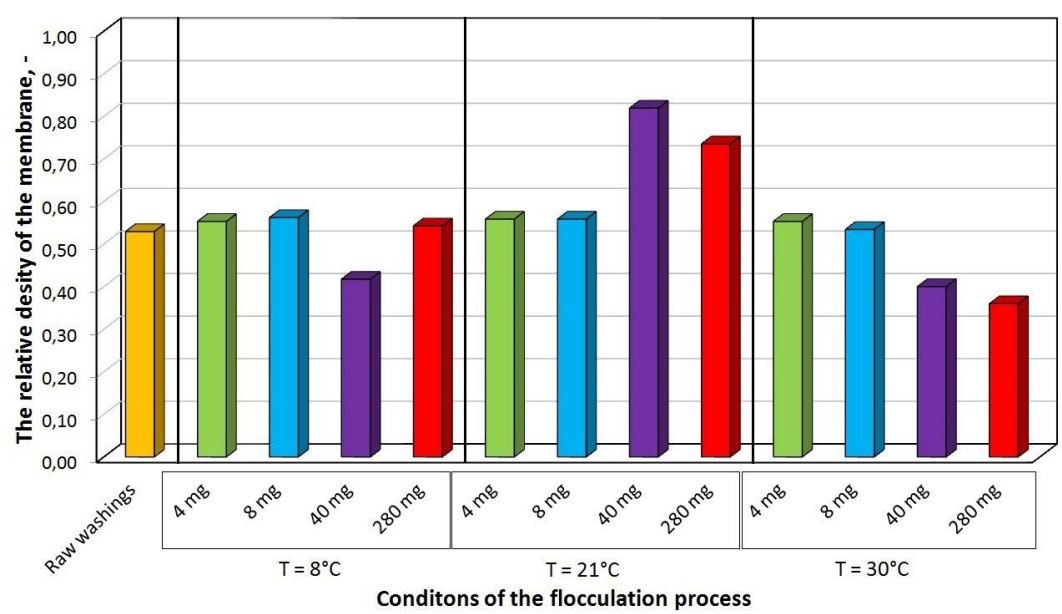

Figure 2. The impact of flocculation carried out at various operational parameters on the transport properties of ultrafiltration membranes $(\mathrm{PAN}, \Delta \mathrm{P}=0.2 \mathrm{MPa})$

a)

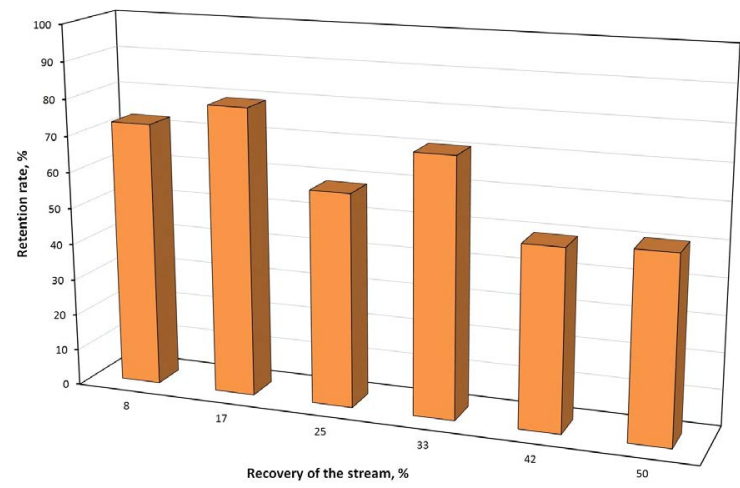

b)

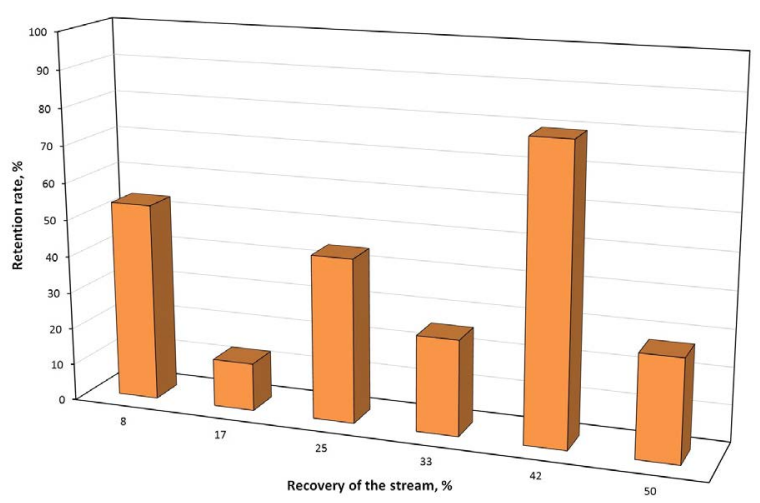

Figure 3. The separation characteristics of the ultrafiltration membrane ( $P A N, \Delta P=0.2 \mathrm{MPa}$ ) upon the filtration of raw washings (i.e. without previous flocculation): a) turbidity; b) $\mathrm{UV}_{254}$ absorbance 
tion rates obtained from the turbidity and $\mathrm{UV}_{254}$ absorbance measurements before and after the filtration process (relative to the percentage permeate recovery stream). The turbidity retention rates ranged from $50 \%$ to $80 \%$ while the $\mathrm{UV}_{254}$ retention rates ranged from $13 \%$ to $80 \%$. No clear correlation could be observed between the duration of the process and the values obtained.

The integrated flocculation/ultrafiltration system was more effective in the removal of contaminants from the tested washings. In addition, increased stability of contaminant rates measured in the permeated was observed for the highest dose of the flocculant $\left(280 \mathrm{mgAl}^{3+} / \mathrm{L}\right)$. Figures $4 \mathrm{a}$ and $4 \mathrm{~b}$ present the contaminant retention rates for ultrafiltration of washings previously subjected to flocculation at $8^{\circ} \mathrm{C}$. High turbidity retention rates were obtained for washings subjected to flocculation with solutions containing 4, 8, 40, and 280 $\mathrm{mgAl}^{3+} / \mathrm{L}$, averaging $92,94,98$, and $95 \%$, respectively. $\mathrm{UV}_{254}$ retention rates for the respective flocculant doses were 48, 64, 88, and 94\%.

Similar contaminant retention rates were obtained for ultrafiltration following flocculation carrier out at $21^{\circ} \mathrm{C}$. Within the studied dose range, turbidity was reduced by $68-99 \%$ and $\mathrm{UV}_{254}$ absorbance was reduced by $47-96 \%$. The changes in contaminant separation parameters are presented in Figures $5 \mathrm{a}$ and $5 \mathrm{~b}$.

The integrated flocculation/membrane ultrafiltration system involving flocculation being carried out at $30^{\circ} \mathrm{C}$ was characterized by the efficacy

a)

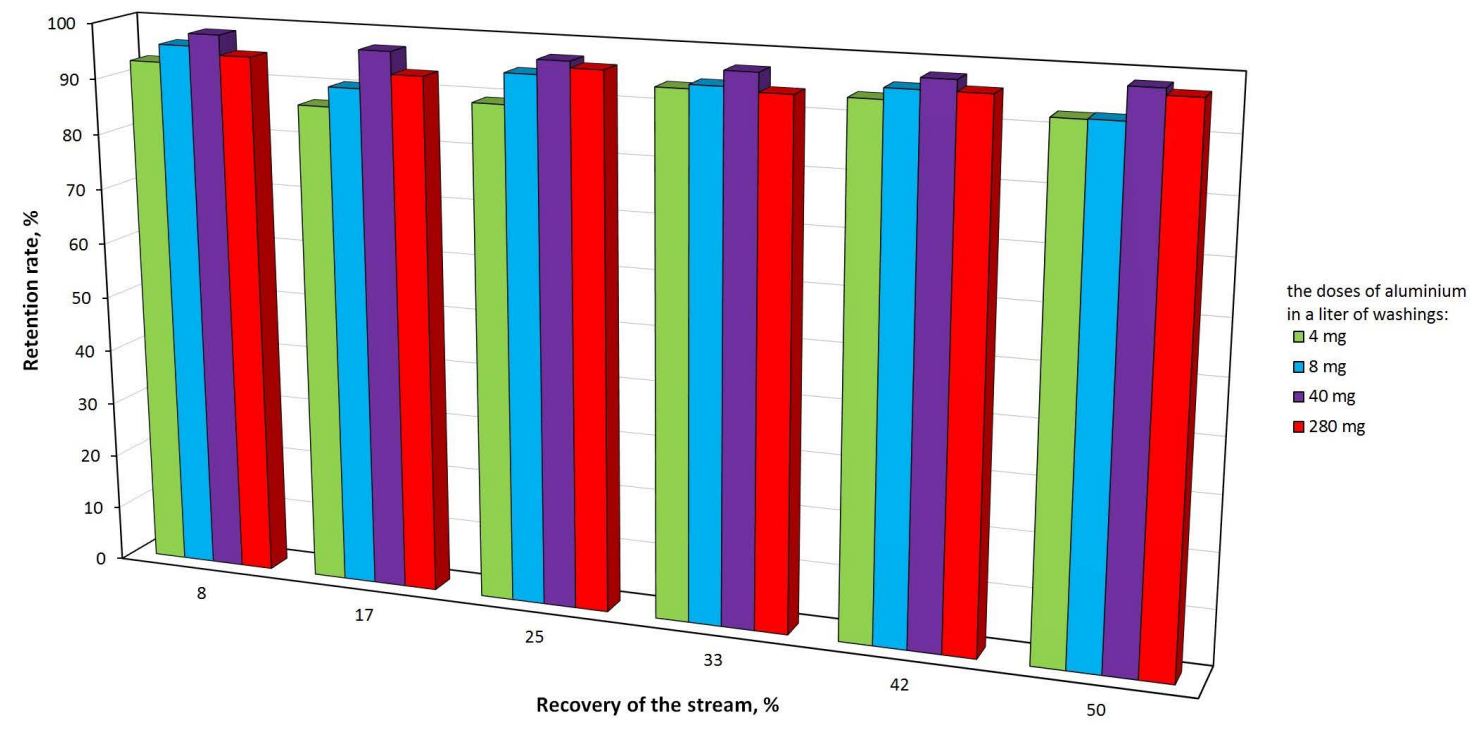

b)

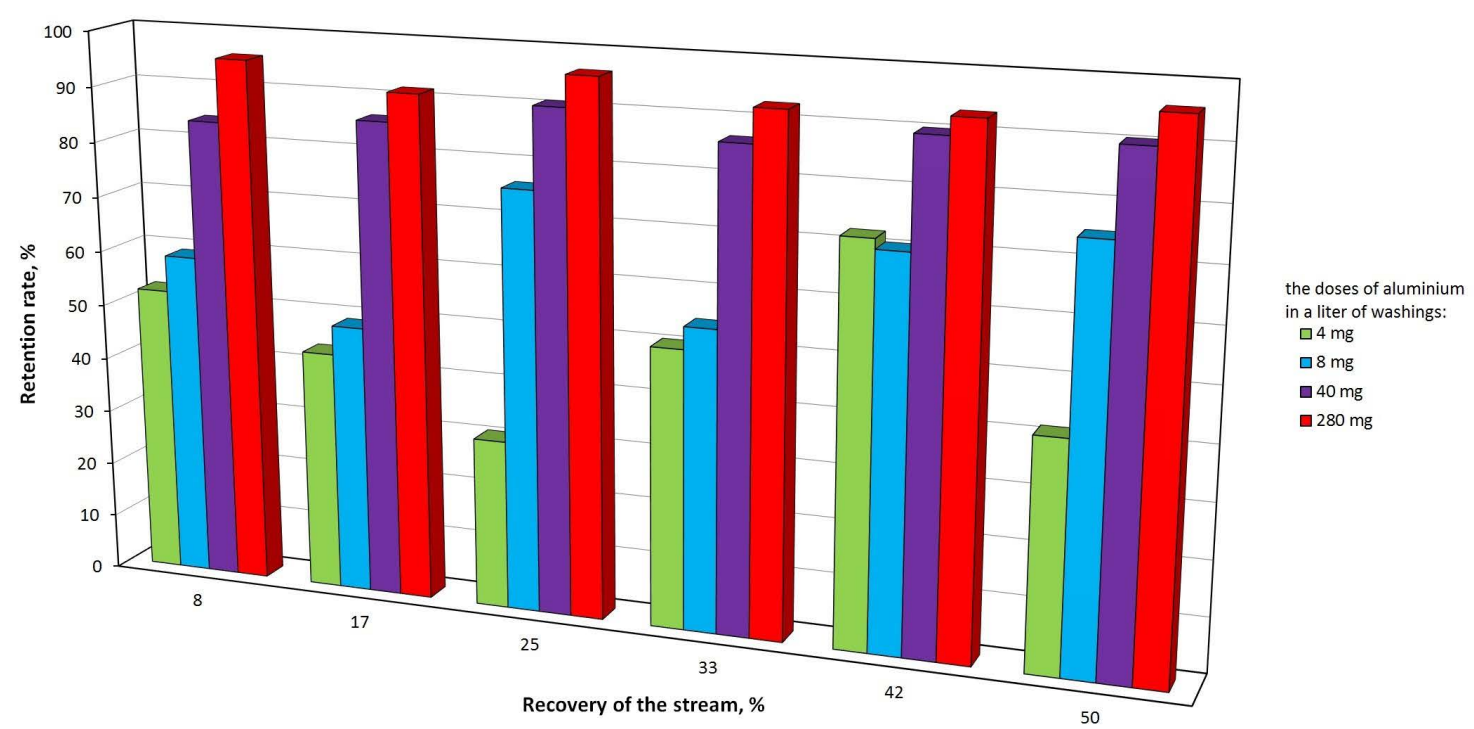

Figure 4. The separation characteristics of the ultrafiltration membrane ( $P A N, \Delta P=0.2 \mathrm{MPa}$ ) upon the filtration of washings previously subjected to flocculation at $8^{\circ} \mathrm{C}$ as determined from the measurements of: a) turbidity; b) $\mathrm{UV}_{254}$ absorbance 
a)

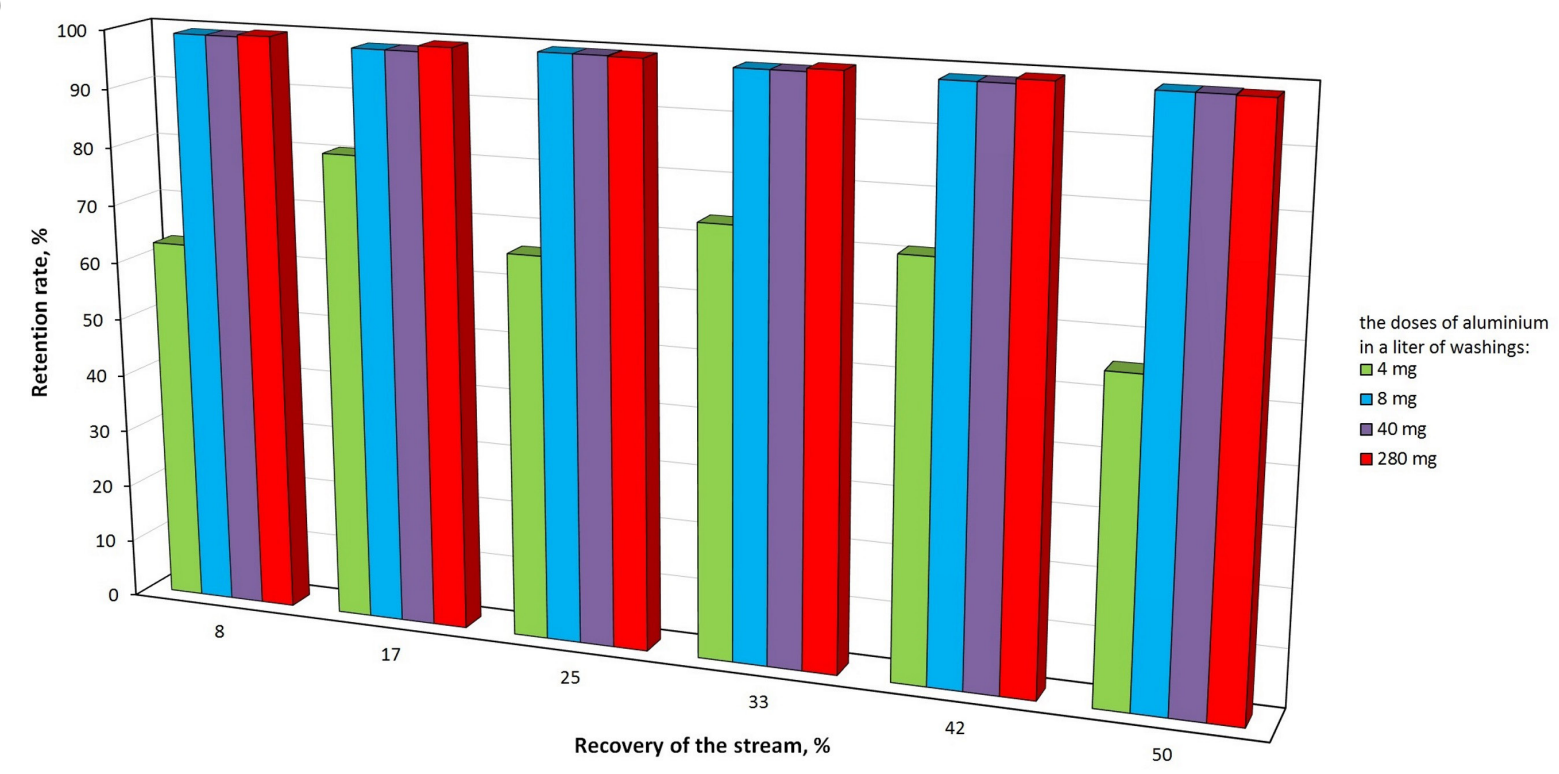

b)

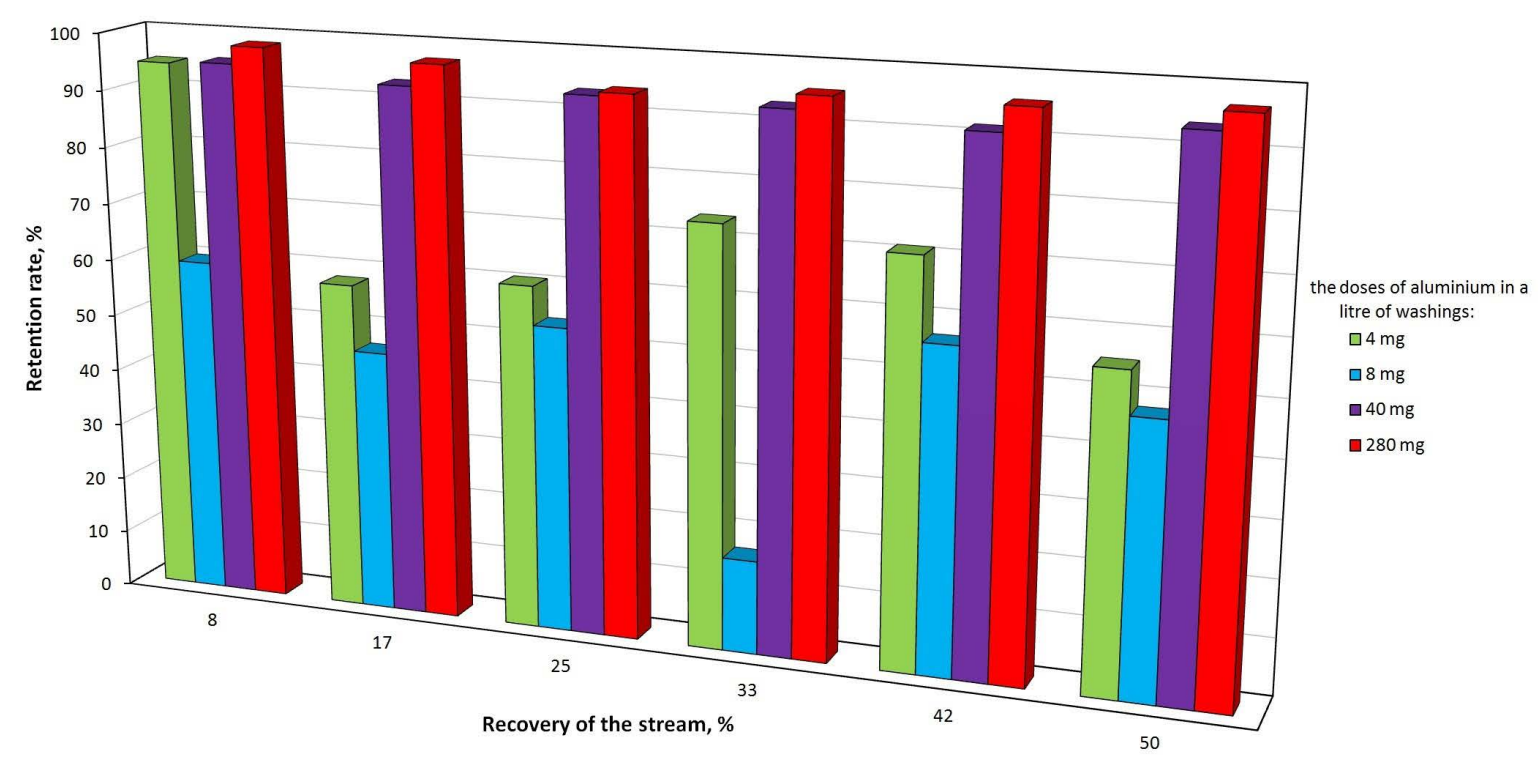

Figure 5. Changes in the separation characteristics of the ultrafiltration membrane ( $P A N, \Delta P=0.2 \mathrm{MPa}$ ) upon the filtration of washings previously subjected to flocculation at $21^{\circ} \mathrm{C}$ as determined from the measurements of: a) turbidity; b) $\mathrm{UV}_{254}$ absorbance

of $\mathrm{UV}_{254}$ absorbance reduction being higher for low flocculant doses $\left(4-8 \mathrm{mgAl}^{3+} / \mathrm{L}\right)$. The retention rates for these doses were $62 \%$ and $71 \%$, respectively. Also the turbidity retention rates were high in the aforementioned conditions, amounting to $94 \%$ and $81 \%$, respectively. Figures $6 a$ and $6 \mathrm{~b}$ present the complete results of the test series discussed above.

\section{CONCLUSION}

Based on the presented studies it may be concluded that flocculation combined with mem- brane ultrafiltration facilitates significant removal of contaminants being present in washings, particularly of suspended contaminants being characterized by the turbidity of the liquid. In addition, the conditions of the flocculation process that facilitated significant improvement of the ultrafiltration membrane transport characteristics were determined. Flocculation carried out at flocculant dose of $40 \mathrm{mgAl}^{3+} / \mathrm{L}$ and at the temperature of $21^{\circ} \mathrm{C}$ afforded an increase in the volumetric stream of the permeate by more than $35 \%$ with the turbidity retention rate of ca. $99 \%$ and $\mathrm{UV}_{254}$ absorbance retention rate of ca. $94 \%$. 
a)

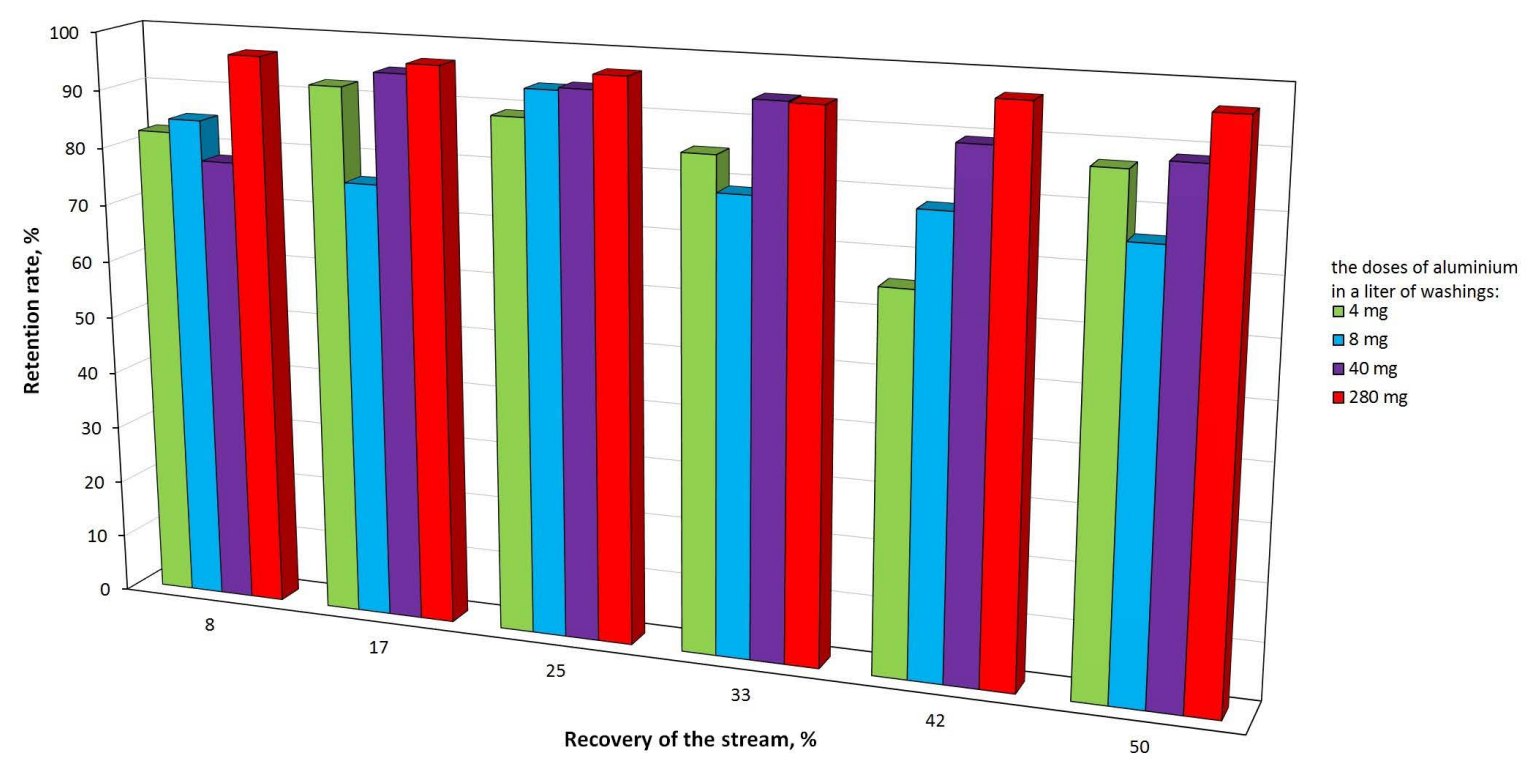

b)

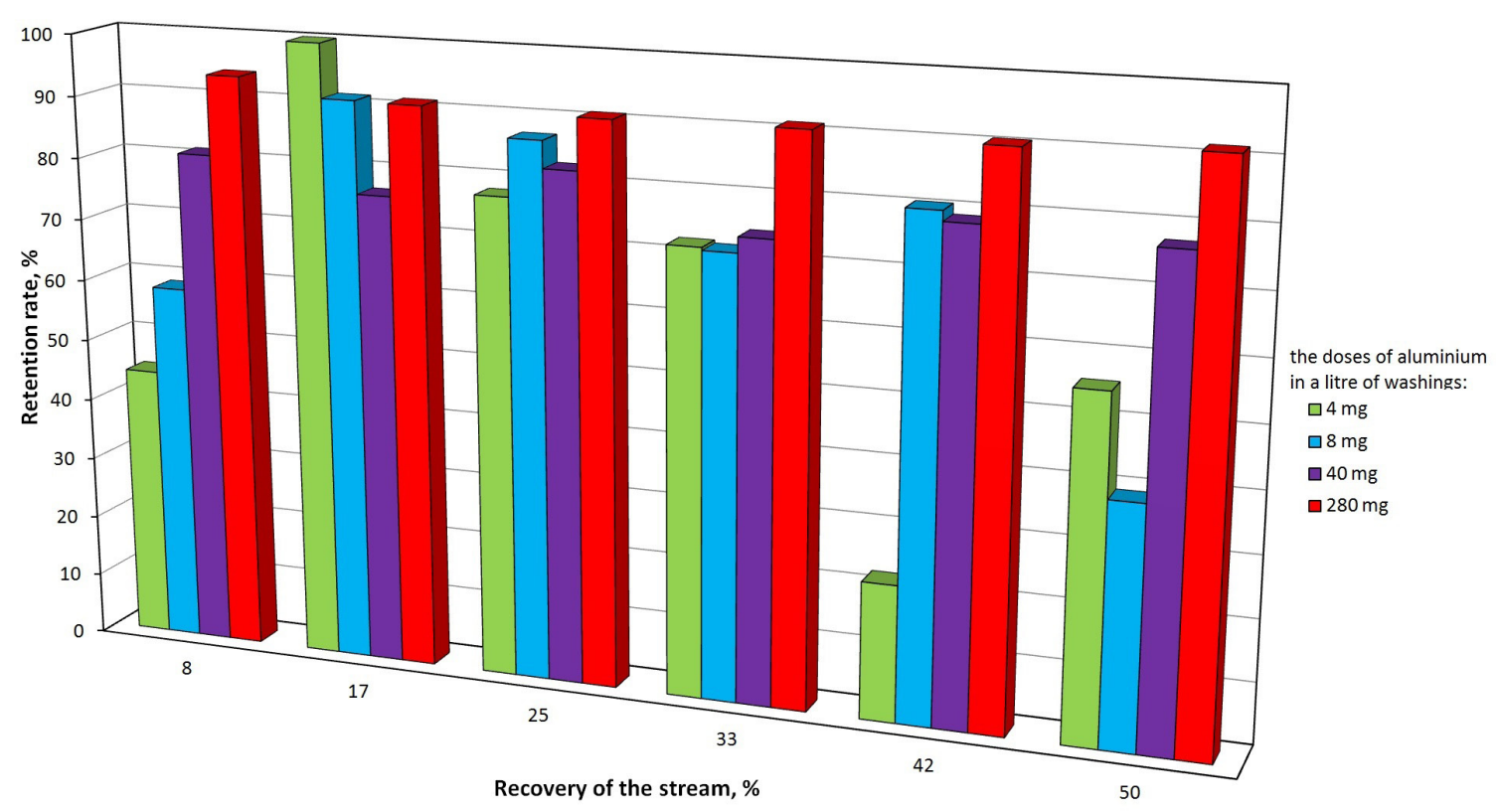

Figure 6. Changes in the separation characteristics of the ultrafiltration membrane ( $\mathrm{PAN}, \Delta \mathrm{P}=0.2 \mathrm{MPa}$ ) upon the filtration of washings previously subjected to flocculation at $30^{\circ} \mathrm{C}$ as determined from the retention rates of: a) turbidity; b) $\mathrm{UV}_{254}$ absorbance

\section{Acknowledgements}

The study was carried out within the framework of the Faculty's research grant for young scientists (BKM-536/RIE-4/15) "Quality assessment of swimming pool water aided with ecotoxicology tools".

\section{REFERENCES}

1. DIN 19643. 1997. Aufbereitung von Schwimm und Badebeckenwasser.
2. Chief Sanitary Inspectorate. 2014. Wytyczne w sprawie wymagań jakości wody oraz warunków sanitarno-higieniczych na pływalniach [Guidelines on water quality and sanitary conditions at swimming pools] www.gis.gov.pl.

3. Łaskawiec E., Dudziak M., Wyczarska-Kokot J. 2016. Oczyszczanie wody popłucznej z instalacji basenowej w jednostkowym membranowym procesie ultrafiltracji oraz $\mathrm{w}$ układzie zintegrowanym napowietrzanie-ultrafiltracja [Treatment of aqueous rinsing liquids of the pool water installation in a unit process of membrane ultrafiltration and in the airing-ultrafiltration integrated system]. Apratura Badawcza i Dydaktyczna, 21(4), 238-245. 
4. Mołczan M., Szlachta M., Karpińska M., Biłyk A. 2006. Zastosowanie absorbancji właściwej w nadfiolecie (SUVA) w ocenie jakości wody [The use of specific ultraviolet absorbance (SUVA) in water quality assessment]. Ochrona Środowiska, 28(4), 11-16.

5. Nowacka A., Włodarczyk-Makuła M. 2012. Zmiany absorbancji w nadfiolecie (UV254) w procesach uzdatniania [Changes in absorbance in the ultraviolet (UV254) treatment processes]. LAB Laboratoria, Aparatura, Badania, 17(1), 28-31.

6. Potter B., Wimsatt J. 2009. Determination of total organic carbon and specific UV absorbance at 254 $\mathrm{nm}$ in source water and drinking water. EPA Document, Method 415.3.

7. Wyczarska-Kokot J. 2016. The study of possibilities for reuse of washings from swimming pool circulation systems. Ecological Chemistry Engineering S, 23(3), 447-459.

8. Wyczarska-Kokot J., Błotnicki M. 2013. Odzyskać i zaoszczędzić. Możliwości recyklingu popłuczyn z systemu oczyszczania wody basenowej, cz. 1 [To recover and save. The possibility of recycling of pool water purification system washings part 1]. Pływalnie i Baseny, 14, 84-89. 